The results were transferred to distribution sheets corresponding to the sheets of the military map and printed on transparent paper with physical features shown on the reverse. These are reduced on to maps showing the whole of the Netherlands on the scale $1: 1,500,000$, of which some 2,500 have been prepared. Finally, Dr. Kloos illustrated various methods of publishing the results which had been tried before the adoption of the present system, which was clear and yet not unduly expensive. The scheme was applied to Bryophytes, Lichens, Fungi and Mollusca in addition to vascular plants.

Prof. A. R. Clapham (University of Sheffield) then reviewed the work of the conference. He said that speakers had demonstrated that an accurate and up-to-date knowledge of distribution was of great and growing importance. Such knowledge could be summarized in a convenient form in revisions of "Topographical Botany" and "Comital Flora", but to these works maps were an indispensable supple. ment. He suggested that in a book of 500-700 pages, each 9 in. $\times 11 \frac{1}{2}$ in., it would be possible to give four maps to the page on a scale of $1: 10,000,000$ to illustrate the distribution of all British vascular plants. He advocated the retention of county boundaries for use in collecting records, and suggested that distribution might be shown by dots where feasible, but where continuous it might be represented by shading showing four degrees of frequency. The ten-kilometre grid might also be employed. Historical information and the location of sub-fossil plants might also be shown.

Many speakers joined in the discussion which followed. An especially valuable contribution came from Prof. Cnut Fægri (University of Bergen), who said that there was a fine tradition of mapping in Scandinavia, where it was possible to map to a great extent from herbarium material. The Uppsala school used a base map with a mass of topographical detail printed in blue which was not reproduced in printing. The Swedes use old administrative boundaries and he saw no reason why we should not continue to do the same, but emphasized that these were of minor interest to botanists abroad and need not be reproduced in the printed maps. All localities should be shown on the maps, but Prof. Fægri suggested that by making the dots larger they would coalesce when distribution is continuous.

After Dr. W. B. Turrill (Royal Botanic Gardens, Kew), Prof. T. G. Tutin (University College, Leicester), Dr. E. F. Warburg (University of Oxford) and others had contributed to the discussion, the conference adopted a proposal that the Council of the Botanical Society of the British Isles should be invited to discuss the possibility of preparing and producing a series of maps of the British flora and, if it was considered practicable, to enlist the cooperation of such other bodies as may be desirable. It was suggested that Prof. Clapham should be asked to attend the meeting at which the proposal is discussed.

Throughout the conference exhibits of herbarium material and maps illustrating distribution were on view, and some of the exhibitors were able to give short talks explaining their exhibits. In addition to those staged in connexion with papers already mentioned, these included: "Distributional Studies and Generic Segregation in Lepturus sensu Bentham" by Mr. C. E. Hubbard (Royal Botanic Gardens, Kew); "The Topocline in Ulmus coritana" by Dr. R. Melville (Royal Botanic Gardens, Kew) ; "Primula elatior" by Miss D. and Mr. H. Meyer; "The Antarctic Origin of some British Carices" by Mr. E. Nelmes (Royal Botanic Gardens, Kew) ; "Distribution Maps of Kent Plants", by Mr. F. Rose (Bedford College, London); "The Distribution of the Digitalis purpurea Complex" by Mr. V. H. Heywood (Cambridge); and "The History and Distribution of some Brambles of S.E. England" by Mr. W. C. R. Watson.

After the programme of papers and discussion, a 'brains trust' again proved a useful and amusing feature. Acting as question-master, Mr. J. S. L. Gilmour introduced the members of the trust: Prof. T. G. Tutin, Drs. R. C. L. Burges, J. M. Lambert and W. B. Turrill, and Messrs. J. P. M. Brenan and R. H. Graham. The questions ranged from the justification for transplanting species to fresh localities to the pronunciation of Erica, and provided much useful expression of opinion in addition to a little amusement for an audience somewhat tired after two long days of serious papers.

The conference concluded with a brief summing-up by the president, who said that the Society would explore the possibility of publishing the Proceedings as they did for the last conference, and would carefully consider the proposals for preparing a set of maps and an annotated list of hybrids. Thanks were expressed to all who had helped towards the success of the conference and particularly to Dr. J. G. Dony, who was responsible for most of the organisation, and Mr. W. R. Price (assistant secretary), who undertook much of the heavy secretarial work entailed.

Two welcome features were the active part taken by botanists from abroad, and the presence and participation of young botanists. Of the former, Dr. Kloos and Prof. Fægri have already been mentioned, and Prof. R. van der Wijk (University of Groningen) also joined in the proceedings. Although time for discussion of the papers was unduly limited, a good proportion of the 160 members and guests who attended were able to contribute. It is hoped that the Botanical Society of the British Isles will be able to carry out some, at least, of the constructive suggestions which were made. J. E. Lousley

\section{BIRMINGHAM MEETING OF THE BRITISH ASSOCIATION}

CINCE its foundation in 1831, the British Associa$\checkmark$ tion for the Advancement of Science has on five occasions held its annual meoting in Birmingham. It met there last in 1913, under the presidency of Sir Oliver Lodge ; this year, when the Association visits Birmingham on the joint invitation of the City and the University, the president will be Sir Harold Hartley.

The meeting will open on the evening of August 30, when the president will deliver his address in the Town Hall. He has chosen the title "Man's Use of Energy", and it would be difficult to find a topic more appropriate to the times, or to the place of the Association's meeting. The Unesco discussion theme for the year is "Energy in the Service of Man", which differs from Sir Harold's title mainly by being capable of translation into French. This same theme will be made prominent during the meeting by discussions in several of the thirteen sections. Civil applications of nuclear energy, the harnessing of chemical energy, the use of power by primitive man, and gas turbines will come under review by the physies, chemistry, 
anthropology and engineering sections respectively. An exhibition illustrating this central topic of the meeting is being organised, and a series of five public lectures on its various aspects will be given in Birmingham by distinguished speakers.

The sectional meetings will be held at Edgbaston (within the city and about three miles from its centre), in the University, King Edward's Schools and the Teachers' Training College.

At a British Association meeting, one is always torn between conflicting attractions, and the same difficulty is met in choosing subjects for mention from among the sectional programmes. A somewhat random selection on the side of the physical sciences includes "Heat Flow in the Earth's Crust" (Section A), "Chemistry of Plastics, Rubbers and Fibres" (Section B), and "Automatic Control Systems" (Section G). On the biological side, interest in Section D will centre on entomological questions, while in Section $\mathrm{K}$ the president's theme of modern trends in classification will be elaborated by a discussion of its cytogenetical aspects in which Section $\mathrm{D}$ will also join. Section $\mathrm{K}^{*}$ (Forestry) will also spend an afternoon discussing the genetical aspects of forestry problems. At first thought, agriculture may seem little related to Birmingham, yet the city is, in fact, the centre of an area with diverse agricultural problems. The surrounding counties are among the best agricultural areas in Great Britain. In the Evesham district there flourishes a special combination of market gardening and agriculture, while even the Black Country has its own problem, that of rehabilitating derelict areas. All these will be reflected in Section M's programme, and Section G is taking up the specially appropriate topic of agricultural engineering. The presidential address to Section $H$, on "The Influence of the Potato on Social Structure", will appeal to a wide biological and agricultural, as well as anthropological, audience. Section B will discuss with Section I the chemistry of muscular contraction, and with Section $K$ the chemistry of the cell and nucleus; while the great attraction of Section $\mathrm{L}$ will be an address by Dr. J. B. Conant, president of Harvard University, on "An Experiment in the Study of Science by Non-scientists".

The Evening Discourses will be given by Prof. $\mathrm{K}$. von Frisch on "The Language of the Bees", by the Bishop of Birmingham (Dr. E. W. Barnes, F.R.S.) on "Science, Religion and Moral Judgment", and by Dr. A. C. B. Lovell on "The New Science of Radio Astronomy".

On Sunday, September 3, the preacher at a special service in St. Martin's Church will be the Very Rev. W. R. Matthews, Dean of St. Paul's. Representatives of the Free Churches will take part in this service.

Excursions for scientific purposes, and for pure pleasure, have long been traditional at British Association moetings. This year's programme is as full and varied as usual, ranging from factories within sight of the meeting-rooms to the source of Birming ham's famous Welsh water in the Elan Valley. Social occasions will include receptions given by the City and the University, and a garden party given by Messrs.* Cadbury, Ltd.

A list is given below of the presidents of Sections and chairmen of Sub-Sections, with the titles of the addresses they will read. Further information about the meeting may be obtained from the Secretary of the British Association, Burlington House, Piccadilly, London, W.1, or from the Local Secretaries for the meeting at the Council House, Birmingham, 1 .
(A) Mathematics and Physics: Prof. E. H. Neville: Mathematical Notation.

(B) Chemistry : Prof. E. L. Hirst: Modern Developments in Carbohydrate Chemistry.

(C) Geology : Dr. W. Campbell Smith: Stony Meteorites.

(D) Zoology: Dr. V. B. Wigglesworth: The Science and Practice of Entomology.

(E) Geography : Prof. S. W. Wooldridge: The Upland Plains of Britain; their Origin and Gec. graphical Significance.

(F) Economics: Prof. G. C. Allen : Economic Progress : Retrospect and Prospect.

(G) Engineering : Prof. Andrew Robertson: A Chapter in Bridge Engineering a Century Ago.

(H) Anthropology and Archæology : Dr. R. N. Salaman: The Influence of the Potato on Social Structure.

(I) Physiology : Prof. R. J. Brocklehurst : Hormones of the Digestive Tract.

(J) Psychology : Dr. J. C. Flugel : Human Affairs and the Psychological Point of View.

(K) Botany : Dr. W. B. Turrill : Modern Trends in the Classification of Plants.

$\left(\mathrm{K}^{*}\right)$ Forestry : The Right Hon. Lord Bolton : Some Post-war Forestry Problems.

(L) Education: W. F. Oalkeshott : Education and Power.

(M) Agriculture: Prof. H. D. Kay : Quality in Agriculture.

\section{THE SPANISH HIGHER COUNCIL FOR SCIENTIFIC RESEARCH}

TUMEROUS representatives recently attended a most interesting and successful meeting in Madrid to celebrate the tenth anniversary of the founding of the Higher Council for Scientific Research. In recent years in all countries, government interest in the development of research facilities has been greatly extended, and various mechanisms for rendering such development possible have been put into operation. One of the most interesting of these is the Spanish experiment, the outcome of which will be well worth watching. Both in the United States and in Great Britain, continuous effort must be exercised to prevent dichotomy arising between governmentsponsored research and university research. Again, the development of research on the arts side proceeds in these countries independently and without any contact with scientific progress. The concept of a 'Higher Council' on which the universities, royal academies, national defence research departments, as well as the schools of mining, of engineering, of fine arts, of sacred and political science are represented is both novel and intriguing in its possibilities.

The Council groups the various branches of science into three sections : physical, biological and spiritual subjects. Each section is composed of two trusts, and the trusts are responsible for the research institutes, museums and sections. There are now more than fifty institutes for which the Council is responsible. These are by no means all situated in Madrid, as it is the policy of the Higher Council to decentralize its activities so far as possible. Thus, for example, the Institute of Parasitology is in Granada, that of church history in Salamanca, of applied chemistry in Saragossa, and in Jaca is the Pyrenean Studies Centre. 